the need to make India self-sufficient for food, instead of relying more and more upon imports.

To effect this, many factors require consideration, and State aid in various directions is essential. Water shortage can be mitigated by irrigation facilities and by the construction of wells in certain areas. Low yields are often due to the selection of unsuitable types of soil for certain crops. Surveys need to be undertaken to adjust this problem, and to determine where poor arable land would be more profitable if it were laid down to pasture or trees. Soil fertility can be improved by raising the organic matter status by encouraging the preparation of composts from farm wastes, town refuse and night soil. Rotation of crops, including the cultivation of legumes, would serve the double purpose of providing valuable essential foodstuffs and raising the nitrogen content of the soil. The available amount of protein for human consumption is definitely inadequate, and the deficiency can only be made good by extensive growth of leguminous crops.

It is calculated that improvement in the quality of the seed sown would result in an increase of 10-20 per cent of crop, and a great extension of seed farms is called for to produce and distribute improved seeds of various crops. The breaking up of fallow land to increase the arable acreage is not always practicable, owing to the need for maintaining adequate pasturage for cattle, which in India are so important as beasts of burden as well as for milk production. Serious attempts are being made to improve the cattle by better methods of breeding, and a necessary corollary to this is a stepping-up of the amount and quality of the available feed. As it is, the existing supplies of fodder and the area under pasture are inadequate, and to avoid the inevitable competition between the utilization of land for human and for cattle food, it is essential for better methods of cultivation and manuring to be adopted in both cases. If this were done, an increase of $25-33$ per cent of human food could be produced from the area at present under the plough, while adequate manuring and appropriate systems of grazing would bring about a corresponding improvement in the supplies for cattle.

Very considerable losses occur in stored grain from weevil attack, at least $1 \cdot 3$ million tons a year being damaged by insects. Rats and spoilage by weather cause further loss, and provision is needed for more adequate storage facilities.

If maximum crop production is to be obtained, it will be necessary for the State to play a part by subsidizing the cultivators, in order to encourage them to use modern methods without the fear of financial loss. The more adequate food supplies thus obtained would so improve the health and strength of the workers as to raise the standard of industrial manufacture as well as that of agriculture.

In order to stabilize the production in India of various crops in general, and food crops in particular, it is essential to consider the long-range problems and prepare a co-ordinated plan to make the country a self-sulficient unit. Experiments are necessary to determine the maximum crop-yielding capacities of soils, special attention being given to the organic matter and nitrogen status of the soils. The standard experiments finally fixed should be conducted simultaneously at various places with different soils and climatic conditions. For this purpose an efficiently trained body of workers is essential, partly to carry out the fundamental research and partly to act as propagandists in making the results known to the agriculturists. After the return of personnel and machinery from war purposes, many men can be used to colonize selected areas and to carry out organized campaigns against diseases and pests of crops, involving the use of specialized machinery, insecticides and fungicides. Many war vehicles could likewise be adapted for power work on the farm for many purposes.

Finally, it is realized that a suitable wage system must be evolved, ensuring a basic wage to the agricultural labourers, rising in accordance with increased costs of living. Such a system, together with certain subsidies to the cultivators, would make for financial stability in the agricultural world.

\section{BIOLOGY OF THE PRAWN LEANDER}

ITTLE is known in detail of the habits of the 1 prawns of the genus Leander, and Dr. H. Höglund's monograph* fills a distinct gap. It is an excellent work and a model for those dealing with the biology and life-history of a single species of prawn. Leander squilla together with the more important Leander adspersus forms a fishery on the west coast of Sweden. The researches have been carried out, partly as field investigations in order to study Leander squilla as a member of a stock, its habits, propagation, growth, etc., under natural conditions in the sea, partly as aquarium experiments in order to study such individual processes as mating, spawning, hatching and moulting.

During the winter, the prawns inhabit deep water. When the water in the upper layers has become warmed in the spring, they begin to appear on the shores, and breeding takes place throughout the summer. Temperaturs is shown to be all-important to migration, bleeding and growth, and the time of arrival of the prawns on the shores varies in different seasons according to conditions. In the autumn they return to deep water. Unlike Leander adspersus, which, according to Mortensen (1897), migrates to deeper and colder water to hatch out the larvæ, Leander squilla apparently remains close to shore in shallow water. The newly hatched larvæ occur in the plankton. It is specially to be noted that the larvæ of both the Leander species occupy the upper layers, whereas all the other carid larvæ of the district frequent the deeper water from 15 to 25 metres.

Both males and females become mature during their second summer, when about a year old. Females may produce two broods in one summer. Larger and older prawns are scarce, but these avoid the nets much more successfully and there is evidence that they may live for three years.

Striking film photographs are given of the pairing, moulting and spawning processes taken in aquaria. The armature of the female thorax and pleopods in the breeding season ("the breeding dress") is very fully investigated and the exact function of each batch of setæ is determined. Most of these setæ are for use only when the eggs are extruded, appearing at the moult preceding spawning and disappearing after the last batch of eggs has hatched out, when another moult takes place.

* "On the Biology and Larval Development of Leander squilla (L.) forma typica de Man." By Hans Höglund. Svenska HydrografiskBiologiska Kommissionens Skrifter, Ny Serie, Biologi, 2, No. 6 (Stockholm, 1943). 
The larvæ of Leander squilla forma typica are described in detail and closely resemble those of $L$. adspersus, although the colour is quite different. Five or six larval stages are recognized, the last stage changing to post-larva. The larval characters of the two species are compared in a table. The whole planktonic larval period lasts for about four weeks, after which the post-larvæ make their way to the shores. This they do very quickly, often before another moult takes place, and the young prawns appear on the shores in enormous quantities.

The illustrations throughout are very good, including clear outline figures in text and plates. The photographic film figures are very illuminating.

\section{FORTHCOMING EVENTS}

\section{Saturday, June 17}

BIochemrcal SocIetr (in the Physiology Department, University College, Dundee), at 2 p.m.

NoRth of England INSTitute of Mining and MechanicaI ENGINEERS (at Neville Hall, Newcastle-upon-Tyne), at 2 p.m.--Mr. Williams, W. Jeffery and A. Taylor: "Outbursts of Gas from the Floor of Coal Seams", Part 1 .

\section{Monday, June 19}

ROYAL GEOGRAPHICAI SOCIETY (at Kensington Gore, London, S.w.7), at 3 p.m.-Annual General Meeting.

Assoctation OF AUSTRIAN ENGINEERS, ChemistS AND SCIENTIFIC WORKERS IN GREAT BRITAIN (at the Institution of Mechanical Engineers, Storey's Gate, St. James's Park, London, S.W.1), at 7.15 p.m. -Prof. P. H. Gross: "Planning and Education for Technical Research".

\section{Tuesday, June 20}

SCIENTIFIC INSTRUMENT MANUFACTURERS' ASSOCIATION (at the Waldorf Hotel, Aldwych, London, W.C.2), at 1 p.m.--Luncheon

RoYal STATISTICAL SOCIETY (at the London School of Hygiene and Tropical Medicine, Keppel Street, London, W.C.1), at 5.15 p.m.Mr. R. J. E. Silvey : "Listener Research".

\section{Wednesday, June 21}

Royal Society of Medicine (joint meeting of the Section of COMPARATIVE MEDICINE with the INSTITUTE FOR THE STUDY ON ANIMAL BEHAVIOUR) (at 1 Wimpole Street. London, W.1), at 2.30 p.m. ing Processes in Animals"; : "Instinct"; ; Dr. W. H. Thorpe : "Learning Processes in Animals"; ; Prof. D. B. Johnstone-Wallace: "Grazing Behaviour in the Male"'

Geological Soctety of London (at Burlington House, Piccadilly, London, W.1), at 3 p.m.-Scientific Papers.

ROYAI METEOROLOGIOAL SOCIETY (at 49 Cromwell Road, London, S.W.7), at 4.30 p.m.-Mr. N. Carruthers: "A Simple Periodoscope for
Meteorological Data". Dr. T. E. Allibone: "Multiple Lightning Strokes".

ZOOLOGICAL SOCIETY OF LONDON (at Regent's Park, London, N.W.8), at 4.30 p.m.-Exhibition of a Cinematograph Film of som Animals taken in the Society's Gardens, with Commentary by Dr. Edward Hindle, F.R.S.;

\section{Saturday, June 24}

Association for Scientific Photography (joint meeting with the SCIRNTIFIC FILMS ASSOCIATION) (at the Large Theatre, Ministry of Information, Malet Street, London, W.C.1), at 3 p.m.-Discussion on Elton: "The Scope and Distribution of Scientific Films" Arthur. Geoffrey Bell : "Shooting Scientific Films"; Dr. J. Yule Bogue "The Production of Scientific Films for Medical and Biological Purposes".)

\section{APPOINTMENTS VACANT}

APPLICATrons are invited for the following appointments on or before the dates mentioned:

LEOTURER IN ENGINEERING in West Africa-The Ministry of Labour and National Service, Room 432, Alexandra House, Kingsway, London, W.C.2 (quoting Reference No. E.836A) (June 21).
PHYsicist for essential War work (work would include experience in various research departments of a North London firm specializing in optical instruments for scientiflc and industrial research and conAlexandra House, Kingsway, London, W.C.2 (quoting Reference No. A.518XA) (June 21).

LECTURER (woman, resident) in BroLOgY at the Cheshire County Training College, Crewe (for Women students)-The Director of Education, County Education Offices, City Road, Chester (June 22).

Graddate Lecturer in General Science-The Principal, Derby Technical College, Normanton Road, Derby (June 23).

LECTURER IN ELFOTRICAL MACHINERY in the Department of Electrical Engineering-The Registrar, King's College, Newcastle-uponTyne 2 (June 24).

TEACHER (full-time) OF GENERAL SCIENCE with qualifications in PHYSICS and CHEMISTRY, in the Junior Technical School of Oldham Municipal Technical College-The Director of Education, Education Municipal Technical College-

Assistant MASTER to take ENgINGERING SUBJEcts (Mechanical or ASSISTANT MASTER to take ENGINGERING SUBJECTS (Mechanical or
Electrical), with subsidiary Mathematics or Drawing, an ASSISTANT Electrical), with subsidiary Mathematics or Drawing, an AsSISTANT Practice, and an ASSISTANT MASTER to take MATHEMATIOS and Scrasce, with subsidiary Drawing-The Principal, Enfleld Technical College, Queensway, Enfield, Middlesex (June 24).

College, Queensway, Enfield, Middlesex (June 24) Technical College-Mr. E. W. Alston, Education Office, Mid-Essex Technical College, Chelmsford (June 24)

PSYCHIATRIC SOCIAL WORKER with qualiflcations in SOCIAL SCIENOE and MENTAL HEALTH-The Director of Education, Education Offices, Middlesbrough (June 24)

EDUCATIONAL PSYCHOLOGIST (man or woman)-The Director of Education, Education Offices, Wolverhampton (June 24)

AGRICULTURAL CHEMIST - The Director of Agriculture, School of Agriculture. Houghall, Durham (June 24)

HORTICULTURAL Assistant (temporary, male or female)-The Clerk to the County Council, County Offices, Sleaford, Lincs. (June 24).

LECTURER IN MECHANICAL ENGINEERING, and a LECTURER IN Mathematics, in the Denbighshire Technical College--The Director of Education, Education Offices, Ruthin, Denbighshire (June 26).

LECTURER (temporary) IN MATHEMatics-The Registrar, King's College, Newcastle-upon-Tyne 2 (June 26).

ENGINEER AND WORKS MANAGER of the Great Berkhamsted Waterworks Undertaking-The Acting Secretary, Great Berkhamsted Waterworks Co., 166 High Street, Berkhamsted (June 30).

SENIOR LECTERER IN SCIENCE with Graduate or equivalent qualifications in PHYSICS and CHEMISTRY, in the Ipswich School of Technology -The Secretary for Education, 17 Tower Street, Ipswich (June 30).

COMBUSTION AND RESEARCH ENGINEER by large organization, with headquarters at Glasgow-The Ministry of Labour and National Service, Room 432, Alexandra House, Kingsway, London, W.C.2 (quoting Reference No. C.2031XA) (July 1).

ASSISTANT LECTURER IN ENGINEERING-The Registrar, The University, Manchester 13 (July 1).

MECHANICAL ENGINEER (with general experience and good Degree) for Research and Development in Steel Tube Industry (Midlands)The Ministry of Labour and National Service, Room 432, Alexandra (July 3).

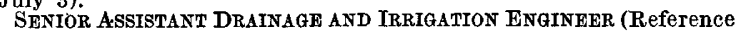
No. E.902A), and a JUNIOR ASSISTANT DRAINAGE AND IRRIGATION No. E.902A), and a JUNIOR ASSISTANT DRAINAGE AND IRRIGATION
ENGINEGR (Reference No. E. 903A), by the Sierra Leone Government ENGINEER (Reference No. E. 903A), by the Sierra Leone Government House, Kingsway, London, W.C.2 (quoting appropriate Reference No.) (July 5). No.) (July 5) ENGrineER by the Sierra Leone Government-The
Ministry of Labour and National Service, Room 432, Alexandra House, Ministry of Labour and National Service, Room 432, Alexandra House, Kingsway,

TTECHNICAL CHEMisT (Reference No. F.2012XA) and a LABORATORY THCHNICAL CHEMIST (Reference No. F.2012XA) and a LABORATORY AssistaNT (Reference No. F.2503XA), by London Paint Manufacturers House, Kingsway, London, W.C.2 (quoting appropriate Reference House, Kingsway (July 8).

ASSISTANT SACRrARY to the Oxford and Cambridge Schools Examination Board-The Chairman of the Oxford Delegacy, St. Catherine's Building, St. Aldate's, Oxford (July 31)

READERSHIP IN PHYSICAI ANTHROPOLOGY-The Registrar, University Registry, Oxford (August 31).

ASSISTANT LECTURER (Grade III) IN THE DEPARTMENT OF ORGaNIo ChEMISTRY-The Registrar, The University, Liverpool.

PSYCHIATRIC SOCIAL WORKER (full-time)-The Secretary, Education office, Trinity Street, Colchester.

Thacher of Mathematics AND Physics in the Handsworth Technical College and Junior Technical School-The Principal, Handsworth Technical College, Golds Hill Road, Birmingham 21.

TEACHER OF SCIENCE (particularly CHEMISTRX) AND MATHEMaTICS and a TEACHER OF MATHEMATICS AND ENGINEERING SUBJECTS, in the Slough Junior Technical and Commercial School-The Secretary for Education, County Offices, Aylesbury, Bucks.

GRADUATE LECTURER IN ScIENCE AND Mathematics--The Clerk to the Governors, Technical College, Chesterfield.

THACHER (temporary) of CHEMISTRY and/or PHYsics, with subsidiary MaThbMaTICs, in the Swansea Technical College-The Director of Education, Education Department, Guildhall, Swansea.

GRADUATE IN PHYSICS, a GRADUATE to teach ELEMENTARY MATHEMATICS and ScIENCE, mainly for work in the Day Technical School for Boys and part-time Day Classes, and a GRADUATE to teach SCIENCE, mainly BroLogr mainly for work in the Day Technical School for Girls of the Maidstone Technical Institute-The District Secretary of the Kent Education Committee, Mr. A. W. Peacock, 13 Tonbridge Road, Maidstone.

PSYCHIATRIC Soorar Worker (full-time)-The School Medical

Officer, Public Health Department, County Hall, Maidstone.

RESEARCH PROFRSSORSHIP IN ANIMAi Health-The Principal,

University College of Wales, Aberystwyth. 